\title{
Pengaruh Persepsi Label Halal Terhadap Preferensi Konsumen pada Restoran Pizza Hut dan KFC di Yogyakarta
}

\author{
Telsy Fratama Dewi Samad \\ Program Studi Magister Studi Islam, Fakultas Ilmu Agama Islam \\ Universitas Islam Indonesia, Yogyakarta \\ Email: telsy_s@ymail.com
}

\begin{abstract}
Halal label has an important role to make consumers recognize easily the quality of products, especially to Muslim consumers. It has enhanced the image of products's cleaness, purity, and no harm. The non-Muslims are also give positif feedback about halal label. This study aims to determine consumers perseption of halal label, the effect perception of halal label on consumers purchasing preference at the Pizza Hut and KFC Restaurant. Determine whether there are differences in consumers's perception of halal label based on gender, religion, educational background, and income. Determine whether there are differences of influence on halal label perception based on gender, religion, education background and income to consumer preferences. This research is quantitative with 200 sample respondents Pizza Hut and KFC, simple random sampling method. The data collection using a likert scale questionaire. Data were analized using Correlation Analysis, Different T-test \& F-test (Anova), and Analisis Multivariat Analysis Varians (Manova). The result found that overall average level of respondents's perception of halal label positif and has significant effect on the preferences. Then the result of analysis differences perseption found that there are significant differences between the perception of consumer halal label based on gender, religion, educational background, while based income level, did not occur significantly different. The result analysis in effect, discover that there were significant differences influent perception of halal label on the characteristics of the consumers purchasing preferences: gender, religion, educational background, and income.
\end{abstract}

Keywords: Halal Label, Perception, Preference, Consumers. 


\begin{abstract}
ABSTRAK
Label halal memiliki peran penting untuk membuat konsumen mengenali dengan mudah kualitas produk, terutama bagi konsumen Muslim. Ini telah meningkatkan citra kebersihan produk, kemurnian, dan tidak ada salahnya. Non-Muslim juga memberikan umpan balik positif tentang label halal. Penelitian ini bertujuan untuk mengetahui persepsi konsumen terhadap label halal, pengaruh persepsi label halal terhadap preferensi pembelian konsumen di Pizza Hut dan KFC Restaurant. Tentukan apakah ada perbedaan persepsi konsumen tentang label halal berdasarkan jenis kelamin, agama, latar belakang pendidikan, dan pendapatan. Tentukan apakah ada perbedaan pengaruh pada label label halal berdasarkan jenis kelamin, agama, latar belakang pendidikan dan pendapatan terhadap preferensi konsumen. Penelitian ini adalah kuantitatif dengan 200 sampel responden Pizza Hut dan KFC, metode simple random sampling. Pengumpulan data melalui kuesioner skala likert. Data dianalisis menggunakan Analisis Korelasi, Uji-T Berbeda \& Uji-F (Anova), dan Analisis Multivariat Analisis Varian (Manova). Hasil penelitian menemukan bahwa secara keseluruhan tingkat rata-rata persepsi responden terhadap label halal baik. Hasil pengujian hipotesis menemukan bahwa persepsi label halal positif dan berpengaruh signifikan terhadap preferensi. Kemudian hasil analisis perbedaan persepsi menemukan bahwa terdapat perbedaan yang signifikan antara persepsi label halal konsumen berdasarkan jenis kelamin, agama, latar belakang pendidikan, sedangkan berdasarkan tingkat pendapatan, tidak terjadi perbedaan yang signifikan. Analisis hasil yang berlaku, menemukan bahwa ada perbedaan yang signifikan persepsi persepsi label halal pada karakteristik preferensi pembelian konsumen: jenis kelamin, agama, latar belakang pendidikan, dan pendapatan.
\end{abstract}

Kata Kunci: Label Halal, Persepsi, Preference, Consumers.

\title{
1. Pendahuluan
}

Pizza Hut merupakan salah satu restoran waralaba internasional yang berpusat di Addison, Texas, USA. Pizza Hut memiliki lebih dari 6000 restoran di Amerika Serikat dan lebih dari 5.139 restoran di 94 negara lain dan wilayah di seluruh dunia (http://www.pizzahutfranchise.com/about-best-pizza-franchise.php). Sementara itu, KFC merupakan franchisor yang paling populer pada rantai restoran daging ayam di dunia, Kolonel Harland Sanders mendirikannya pada tahun 1952. Jumlah restoran yang telah beroperasi adalah lebih dari 17.000 restoran di Amerika Serikat dan termasuk negara lainnya (http://www.kfcfranchise.com/about-KFC-fried-chicken-business.php). Restoran Pizza Hut yang pertama kali beroperasi di Indonesia tahun 1984 merupakan restoran pizza pertama di Indonesia. Sedangkan KFC didirikan pada tahun 1978, 
dan beroperasi pada bulan Oktober 1979 (http://id.wikipedia.org/wiki/KFC). Kedua restoran ini telah memiliki sertifikasi/ label halal dari MUI, dibandingkan dengan beberapa restoran besar lainnya di Indonesia yang belum berlabel halal seperti J.Co Donuts \& Coffee, Solaria, Breadtalk, dan perusahaan makanan dan restoran lainnya yang memiliki kasus ketidakhalalan dan menghebohkan umat $\begin{array}{lllll}\text { muslim } & \mathrm{di} & \text { Indonesia pada bulan oktober } 2013\end{array}$ (http://www.islampos.com/restoran-tanpa-sertifikat-halal-81426).

Pada zaman dahulu, seseorang akan dengan mudah mengetahui dan mengidentifikasi mana makanan yang halal dikonsumsi. Berbeda dengan sekarang ketika kemajuan IPTEK telah berkembang pesat, termasuk di dalamnya teknologi pada pengolahan makanan. Meskipun sudah dicantumkan komposisinya dalam setiap kemasannya, hal itu tetap saja sulit dipahami karena menggunakan istilahistilah ilmiah yang sulit dipahami oleh orang awam. Akibatnya kita digemparkan oleh isu lemak babi dan sapi celeng yang kemudian berkembang menjadi isu nasional dan berdampak pada perekonomian (Sopa, 2013).

Berangkat dari permasalahan diatas, menjadi suatu hal yang penting untuk mengkaji persoalan kehalalan makanan. Penelitian dipusatkan di Kota Yogyakarta sebagai pusat Kota pelajar di Indonesia yang dihuni oleh beragam masyarakat dari berbagai daerah, sehingga dapat membantu merepresentasikan hasil penelitian dari beragam konsumen Pizza Hut dan Kentucky Fried Chicken (KFC) yang ada di Kota Yogyakarta. Tujuan penelitian ialah: (a) Mengetahui bagaimana persepsi konsumen terhadap label halal; (b) Mengetahui bagaimana pengaruh persepsi label halal terhadap preferensi beli konsumen di Restoran Pizza Hut dan Kentucky Fried Chicken (KFC); (c) Mengetahui apakah terdapat perbedaan persepsi konsumen tentang label halal berdasarkan karakteristik konsumen, yaitu jenis kelamin, agama, latar belakang pendidikan, dan pendapatan; serta (d) Mengetahui apakah terdapat perbedaan pengaruh label halal berdasarkan karakteristik konsumen, yaitu jenis kelamin, agama, latar belakang pendidikan, dan pendapatan, terhadap preferensi beli konsumen di Restoran Pizza Hut dan Kentucky Fried Chicken (KFC).

\section{Kajian Pustaka}

Aris dan Marsudi (2011), dalam Persepsi Label Halal Terhadap Keputusan Pembelian Konsumen Pada Produk Minuman Berenergi. Berdasarkan hasil dari penelitian ini dengan alat pengujian analisis linier berganda terdapat beberapa kesimpulan yang diambil: pertama, variabel perhatian (X1), pemahaman (X2), dan ingatan (X3) secara simultan berpengaruh terhadap keputusan pembelian konsumen (Y). Sedangkan diantara ketiga variabel bebas tersebut, hanya variabel pemahaman saja yang tidak berpengaruh secara parsial terhadap variabel dependen. Kedua, hasil penelitian menunjukkan tingkat signifikasi hubungan atau korelasi antara variabel perhatian, pemahaman, ingatan dengan keputusan pembelian. 
Endang (2010) dalam Business Opportunities for Halal Products in The Global Market: Muslim Consumer Behaviour and Halal Food Consumption. Penelitian ini bertujuan untuk meneliti perilaku konsumen Muslim dalam hal makanan, terutama perilaku orang-orang yang tinggal di daerah perkotaan. Hasil penelitian ini menjukkan bahwa kesadaran Muslim di Banten tentang halal-haram makanan cukup tinggi, terutama dalam memilih makanan sebelum mereka makan, seperti daging, ikan dan sayuran. Mereka secara konsisten menempatkan prioritas tinggi pada masalah kehalalan ketika mereka membeli makanan, membeli daging atau memilih restoran tempat mereka makan.

Asadollah, et al (2013) dalam Studying Affecting Factors on Customers's Attitude toward Product with Halal Brand. Saat ini, konsep halal tidak hanya sekedar sebuah masalah dalam agama, tetapi juga dapat membuka kesempatan untuk meningkatkan penjualan dan memperoleh keunggulan kompetitif. Hasil dari penelitian ini menunjukkan dampak yang signifikan dari periklanan. Produk halal memiliki kualitas yang relatif baik dan mempengaruhi baik dari segi agama, hambatan mengkonsumsi, dan sikap konsumen terhadap produk lainnya.

Faryal, et al (2011) dalam An Exploratory Study for Measuring Consumers Awareness and Perception towards Halal Food in Pakistan. Dimana tujuan dari penelitian ini adalah untuk mengukur kesadaran dan persepsi makanan halal di Pakistan sebagai negara Muslim. Hasil penelitian menyatakan bahwa agama merupakan sumber dari segalanya dan merupakan keyakinan bagi konsumen Muslim, keyakinan merupakan rajutan erat dengan komitmen keagamaan, serta sikap dan respon terhadap makanan halal.

Melissa, et al (2009) dalam Halal Food in New Zealand Restorant: An Exploratory Study. Penelitian ini dilakukan di New Zealand sebagai eksportir utama dan produser penyembelihan daging halal di dunia, yang menjadi tujuan aktif untuk setiap wisatawan Muslim. Hasil dari penelitian ini menunjukkan bahwa persentase besar dari sampel tidak setuju bahwa pasar turis Muslim signifikan terhadap bisnis mereka. Dikarenakan banyak juga yang enggan untuk mempromosikan makanan halal atau memasang tanda halal pada toko mereka.

\section{Metode Penelitian}

Dalam penelitian ini, digunakan korelasi Pearson product moment, yaitu untuk mencari arah dan kekuatan hubungan antara variabel bebas $(\mathrm{X})$ dengan variabel tak bebas (Y). Pada penelitian ini, n merupakan (=) jumlah data (responden), selanjutnya $\mathrm{X}$ sebagai variabel bebas adalah persepsi label halal, sedangkan Y sebagai variabel terikat adalah preferensi beli konsumen. Selanjutnya, uji perbedaan digunakan untuk mengetahui apakah ada perbedaan antara satu kelompok dengan kelompok lainnya. Jika ada perbedaan kelompok manakah yang berbeda. Pada uji ini dilakukan uji beda persepsi kepada konsumen dengan berbagai karakteristiknya. Uji-t dilakukan untuk membandingkan rata-rata untuk dua kelompok yang tidak berhubungan satu sama lain untuk mengetahui apakah 
kedua kelompok tersebut mempunyai rata-rata yang sama atau tidak secara signifikan.

\section{Pengaruh Persepsi Label Halal terhadap Preferensi Beli Konsumen pada Restoran Pizza Hut dan Kentucky Fried Chicken (KFC)}

Hasil deskriptif tentang tingkat persepsi label halal menunjukkan bahwa sebagian besar jawaban responden adalah setuju pada sebagian besar item pertanyaan. Nilai rata-rata keseluruhan menunjukkan angka 3,88 berarti secara keseluruhan rata-rata tingkat persepsi responden terhadap label halal adalah baik karena berada pada interval 3,41-4,20. Tingkat persepsi yang paling baik terjadi pada definisi halal adalah semua makanan yang boleh dikonsumsi menurut syariat Islam dengan rata-rata 4,42 (Sangat baik). Sedangkan tingkat persepsi terendah responden terjadi pada item tentang ingatan lebel halal ketika akan mengkonsumsi makanan dengan rata-rata sebesar 3,62 walaupun masih dalam kriteria yang baik.

Berdasarkan analisis korelasi yang dilakukan, diperoleh nilai koefisien korelasi (rxy) sebesar 0,265 dan probabilitas sebesar 0,000<0,05. Dengan demikian terdapat pengaruh positif dan signifikan antara persepsi label halal dengan preferensi beli. Semakin baik persepsi konsumen terhadap label halal, maka preferensi beli konsumen juga semakin meningkat. Dengan demikian hipotesis pertama yang menyatakan "terdapat pengaruh antara persepsi label halal terhadap preferensi beli konsumen di Restoran Pizza Hut dan Kentucky Fried Chicken (KFC) di Yogyakarta" dapat didukung.

\subsection{Perbedaan Persepsi Label Halal diantara Konsumen}

Uji hipotesis dilakukan untuk mengetahui apakah terdapat perbedaan persepsi tentang label halal diantara konsumen pada berbagai karakteristik yaitu: jenis kelamin, agama, latar belakang pendidikan dan pendapatan. Untuk menguji perbedaan tingkat persepsi. Untuk menguji hipotesis kedua digunakan uji t dan Anova. Uji t digunakan untuk menguji perbedaan persepsi label halal berdasarkan jenis kelamin dan agama, sedangkan Anova (Uji F) digunkaan untuk membedakan persepsi label halal berdasarkan latar belakang pendidikan dan tingkat penghasilan.

Pada konteks perbedaan persepsi berdasarkan jenis kelamin, digunakan T-test untuk sampel yang tidak berkorelasi. T-test dilakukan dengan membandingkan skor rata-rata kedua sampel yang diperoleh dari subjek berbeda. Output group statistics menunjukkan bahwa tingkat persepsi perempuan tentang label halal lebih baik dibandingkan responden pria. Output independent samples Test menampilkan Levene's Test untuk kesamaan varian. Dari hasil perhitungan analisis Levene's Test dapat dilihat angka signifikansi sebesar 0,173 dan jika dibandingkan dengan pedoman pengambilan keputusan, maka terlihat bahwa $0,173>0,05$ yang berarti data memiliki varian yang sama atau dapat dikatakan model telah memenuhi asumsi homogenitas. Hasil T-test sebesar -2,293 dan 
probabilitas sebesar $0,023<0,05$ secara statistik terdapat perbedaan signifikan persepsi tentang label halal diantara konsumen Restoran Pizza Hut dan Kentucky Fried Chicken (KFC) di Kota Yogyakarta berdasarkan jenis kelamin. Dengan demikian hipotesis kedua dalam penelitian ini didukung.

Selanjutnya, pada aspek perbedaan persepsi berdasarkan Agama, dari hasil perhitungan analisis Levene's Test dapat dilihat angka signifikansi sebesar 0,000 dan jika dibandingkan dengan pedoman pengambilan keputusan, maka terlihat bahwa $0,000<0,05$ yang berarti data memiliki varian yang tidak sama atau dapat dikatakan model tidak memenuhi asumsi homogenitas. Dari tabel terlihat hasil Ttest sebesar 15,688 dan probabilitas sebesar 0,000 $<0,05$. Dengan demikian secara statistik terdapat perbedaan secara signifikan persepsi tentang label halal diantara konsumen Restoran Pizza Hut dan Kentucky Fried Chicken (KFC) di Kota Yogyakarta berdasarkan agama. Dengan demikian hipotesis kedua dalam penelitian ini didukung.

Di sisi lain, perbedaan persepsi berdasarkan tingkat pendidikan menunjukkan bahwa tingkat persepsi responden dengan latar belakang pendidikan Islam tentang label halal lebih baik dibandingkan responden yang berlatar belakang pendidikam umum maupun Non Islam. Hasil F-test sebesar 21,912 dan probabilitas sebesar $0,000<0,05$. Dengan demikian secara statistik terdapat perbedaan secara signifikan persepsi tentang label halal diantara konsumen Restoran Pizza Hut dan Kentucky Fried Chicken (KFC) di Yogyakarta berdasarkan latar belakang pendidikan. Dengan demikian hipotesis kedua dalam penelitian ini didukung.

Perbedaan persepsi berdasarkan tingkat pendapatan, menunjukkan bahwa output group statistics tingkat persepsi responden dengan tingkat pendapatan yang berbeda-beda memiliki persepsi yang hampir sama, hasil F-test sebesar 1,664 dan probabilitas sebesar 0,145>0,05. Dengan demikian secara statistik tidak terdapat perbedaan secara signifikan persepsi tentang label halal diantara konsumen Restoran Pizza Hut dan Kentucky Fried Chicken (KFC) di Yogyakarta berdasarkan tingkat pendapatan. Dengan demikian hipotesis kedua dalam penelitian ini tidak didukung.

Untuk menguji hipotesis ketiga digunakan uji Multivarian Analisis of Variance (MANOVA). Hasil F-test sebesar 354,982 dengan nilai probabilitas sebesar 0,000 $<0,05$. Dengan demikian terdapat perbedaan pengaruh persepsi label halal terhadap preferensi beli konsumen berdasarkan agama pada Restoran Pizza Hut dan Kentucky Fried Chicken (KFC) di Kota Yogyakarta. Dengan demikian hipotesis ketiga penelitian dapat didukung. Hasil F-test sebesar 4.165 dengan nilai probabilitas sebesar $0,043<0,05$. Dengan demikian terdapat perbedaan pengaruh persepsi label halal terhadap preferensi beli konsumen berdasarkan pendidikan pada Restoran Pizza Hut dan Kentucky Fried Chicken (KFC) di Kota Yogyakarta. Dengan demikian hipotesis ketiga penelitian dapat didukung. Hasil F-test sebesar 6,860 dengan nilai probabilitas sebesar $0,009<0,05$. Dengan demikian terdapat perbedaan pengaruh persepsi label halal terhadap preferensi beli konsumen 
berdasarkan pendapatan di Restoran Pizza Hut dan Kentucky Fried Chicken (KFC) di Yogyakarta. Dengan demikian hipotesis ketiga penelitian dapat didukung.

\section{Kesimpulan}

Hasil penelitian menemukan bahwa dari 200 responden yang diteliti dalam penelitian ini rata-rata memberikan persepsi sebesar 3,88 berarti secara keseluruhan rata-rata tingkat persepsi responden terhadap label halal adalah baik karena berada pada interval 3,41-4,20. Tingkat pemahaman yang paling baik terjadi pada definisi halal adalah semua makanan yang boleh dikonsumsi menurut syariat Islam dengan rata-rata 4,42 (Sangat baik). Sedangkan tingkat persepsi terendah responden terjadi pada item tentang ingatan lebel halal ketika akan mengkonsumsi makanan dengan rata-rata sebesar 3,62 walaupun masih dalam kriteria yang baik.

Secara keseluruhan setiap responden memiliki pemahaman yang baik tentang label halal baik dilihat dari sisi karakteristiknya, yaitu jenis kelamin, agama, latar belakang pendidikan dan pendapatan konsumen. Penelitian ini menggaris bawahi persepsi tentang label halal dari sisi konsumen Muslim dan konsumen nonMuslim, baik dari sisi agama maupun latar belakang pendidikan. Hal ini menunjukkan bahwa persepsi label halal tidak hanya dipahami oleh konsumen Muslim atau konsumen yang berlatar belakang pendidikan Islam saja, namun konsumen non-Muslimpun dan yang berlatar pendidikan berbasis umum hingga berbasis agama selain Islam memiliki persepsi positif terhadap label halal, sekalipun pemahamannya tidak sebaik konsumen Muslim.

Mengingat bahwa negara Indonesia merupakan negara dengan mayoritas penduduk beragama Muslim, namun demikian di Indonesia juga terdapat banyak penduduk non-Muslim. Dimana penduduk non-Muslim di Indonesia hidup berdampingan dengan mayoritas masyarakat Muslim di Indonesia, sehingga logo label halal MUI bukan lagi merupakan hal yang asing. Logo label halal secara tidak langsung membentuk persepsi konsumen terhadap label halal tersebut tidak hanya kepada konsumen Muslim namun juga konsumen non-Muslim. Sehingga walaupun responden yang diteliti dalam penelitian tidak seluruhnya merupakan masyarakat muslim yaitu terdapat $30 \%$ konsumen non muslim, namun mereka memahami dengan baik apa yang dimaksud dengan label halal. Dimana label halal merupakan surat keterangan halal (Fatwa halal) atas suatu produk pangan yang dibuat secara tertulis yang dikeluarkan oleh Majelis Ulama Indonesia (MUI) sebagai pihak yang berwenang mengeluarkan fatwa di Indonesia.

Hasil pengujian hipotesis pertama menemukan bahwa persepsi tentang label halal berpengaruh positif dan signifikan terhadap preferensi beli. Hal ini berarti semakin besar persepsi konsumen tentang label halal maka preferensi belinya akan semakin meningkat. Produk halal memiliki kualitas yang relatif baik dan mempengaruhi baik dari segi agama, hambatan mengkonsumsi, dan sikap 
konsumen terhadap produk lainnya. Sehingga mental pelanggan percaya terhadap produk dengan merek halal.

Hasil hipotesis kedua yaitu analisis perbedaan menemukan bahwa terdapat perbedaan secara signifikan persepsi tentang label halal diantara konsumen Restoran Pizza Hut dan Kentucky Fried Chicken (KFC) di Kota Yogyakarta dengan berbagai karakteristik yaitu berdasarkan jenis kelamin, agama, dan pendidikan. Sedangkan berdasarkan tingkat pendapatan tidak terjadi perbedaan secara signifikan. Hasil penelitian ini menunjukkan bahwa responden wanita memiliki tingkat persepsi yang lebih tinggi dibandingkan dengan responden pria. Begitu juga ditinjau dari agama dan tingkat pendidikan yang berlatar belakang agama Islam memiliki tingkat persepsi tentang lebel halal yang lebih tinggi dibandingkan non Islam.

Dari hasil hipotesis ketiga yaitu analisis perbedaan pengaruh antara persepsi label halal terhadap preferensi beli menunjukkan adanya perbedaan yang signifikan pengaruh label halal berdasarkan karakteristik konsumen (jenis kelamin, agama, pendidikan, dan pendapatan) terhadap preferensi beli konsumen di Restoran Pizza Hut dan Kentucky Fried Chicken (KFC). Hal ini menunjukkan bahwa dalam karakteristik konsumen yang berbeda ternyata besarnya pengaruh antara persepsi label halal terhadap preferensi beli juga berbeda.

Sebagai contoh warga non Muslim yang menyatakan bahwa label halal adalah baik akan mempengaruhi mereka membeli produk tersebut, bukan berarti bahwa mereka tidak membeli produk non-halal. Motivasi mereka melakukan pembelian produk karena label halal telah meningkatkan citra produk sebagai produk yang bersih, suci dan tidak membahayakan, bukan karena untuk melaksanakan syariat Islam. Berbeda dengan orang Muslim dimana preferensi beli terhadap produk yang berlabel halal karena takut kepada Allah SWT jika mereka mengkonsumsi makanan yang tidak halal.

\section{Daftar Pustaka}

Aris Setyawan Prima Sandi, dkk, "Persepsi Label Halal Terhadap Keputusan Pembelian Konsumen Pada Produk Minuman Berenergi”, Jurnal Manajemen Bisnis, Volume 1 No. 0, Tahun 2011, hal. 10-12

Asadollah Kordnaeij dkk, "Studying Affecting Factors on Customers's Attitude Toward Product with Halal Brand", International Research Journal of Applied and Basic Sciences, Vol.4, No. 10, Tahun 2013, hal. 313-314

Endang Soesilowati, "Business Opportunities for Halal Products in The Global

Market: Muslim Consumer Behaviour and Halal Food Consumption”, Journal of Indonesian Social Science and Humanity, Vol.3, Tahun 2010, hal. 151160

Faryal Salman dan Kamaran Siddiqui, "An Exploratory Study for Measuring Consumers Awareness and Perception Towards Halal Food in Pakistan", 
Interdiciplinary Journal of Contemporary Research in Business", Vol.3, No.2, Tahun 2011, hal. 639-649

Wan Melissa Wan Hassan dan Khairil Wahidin Awang, "Halal Food in New Zealand Restorant: An Exploratory Study", International Journal of Economic and Manajement, Vol. 3, No.2, Tahun 2009, hal 385-402

Books

Assael \& Henry. 1992. Consumer Behavior and Marketing Action. Fourth Edition. New Jersey: Prentice Hall

Bambang Prasetyo dan Lina Miftahul Jannah. 2005. Metode Penelitian Kuantitatif: Teori dan Aplikasi. Jakarta: Raja Grafindo Persada

Hansen, M.R., N. Nohria, \& T. Tierney. 1999. What's Your Strategy for Managin Knowledge. Inggris: Harvard Business Review

Hartono. 2013. SPSS 16.0: Analisis Data Statistika dan Penelitian. (Yogyakarta: Pustaka Pelajar

Anto, Hendrie. 2003. Pengantar Ekonomika Mikro Islami. Yogyakarta: EKONISIA

Khaf, Monzer. 1992. Theory of Consumption. dalam Tahir, Sayyed (et al, ed), Reading in Micro economics: an Islamic Perspective, (Longman Malaysian Sdn. Bhd)

Siregar, Syofian. 2013. Metode Penelitian Kuantitatif: Dilengkapi dengan Perbandingan Perhitungan Manual dan SPSS. Jakarta: Kencana

Sopa. 2013. Sertifikasi Halal Majelis Ulama Indonesia: Studi atas Fatwa Halal MUI terhadap Produk Makanan, Obat-obatan dan Kosmetika. Jakarta: GP Press

Sutisna. 2002. Perilaku Konsumen dan Komunikasi Pemasaran. (Bandung: PT Remaja Rosdakarya

Website

http://www.pizzahutfranchise.com/about-best-pizza-franchise.php http://www.kfcfranchise.com/about-KFC-fried-chicken-business.php http://id.wikipedia.org/wiki/KFC http://www.halalmui.org/images/stories/pdf/LSH/produkhalal.pdf http://www.islampos.com/restoran-tanpa-sertifikat-halal-81426/ 